\title{
O Beco dos Artistas e a Subversão das Normas de Gênero
}

\author{
Andressa de Freitas Ribeiro \\ Universidade Federal da Bahia, Salvador, Brasil \\ E-mail: andressa.antropologia@gmail.com
}




\section{Resumo}

O presente artigo é resultado de uma etnografia realizada, durante três anos, sobre um espaço de sociabilidade GLS denominado Beco dos Artistas, em Salvador-BA. Neste trabalho, pretendese articular teoria e prática e, para isso, recorre-se a teorias que versam sobre o corpo e o gênero e são analisados os dados que emergem do campo à luz dessas reflexões teóricas. A título de apresentação, o Beco dos Artistas possuía, no período de campo, quatro bares - Green Bar, Bar Cultural, Bar de Eduardo e Camarim - e o espaço da rua. Os relatos contidos neste artigo versam tanto sobre o comportamento quanto sobre as práticas dos frequentadores nesses espaços.

Palavras-chave: O Beco dos Artistas. Gênero. Corpo e Comportamento.

\section{Abstract}

This article is the result of an ethnography conducted, during three years, about a space of GLS sociability, named Beco dos Artistas, in Salvador$B A$. This article attempts to articulate theory and practice, for it, it uses theories that deal with the body and the gender and analyzes the informations that emerge from the field through these theoretical reflections. For presentation, the place had, in the fieldwork period, four bars - Green Bar, Bar Cultural, Bar de Eduardo and Camarim - and the space of the street. The reports contained in this article talk about the behavior and the practices of the people in these spaces.

Keywords: Beco dos Artistas. Gender. Body and Behavior. 


\section{Introdução}

耳 ste artigo versa sobre o comportamento dos frequentadores de Uum espaço de sociabilidade GLS, em Salvador - BA, cujo nome é Beco dos Artistas. O Beco dos Artistas é uma ruela cuja frente dá para a avenida principal do bairro Garcia - a Av. Leovigildo Filgueiras - e o fundo dá para uma comunidade de moradores, em sua maioria, evangélicos. Essa ruela possui certa invisibilidade; essa característica se apresentou como fundamental para que dentro daquele espaço fosse possível a expressão de práticas, desejos e comportamentos que ainda são reprimidos fora do Beco.

O Beco dos Artistas possui quatro bares - o Green Bar, o Bar Cultural, o Bar de Eduardo e o Camarim. Esses bares funcionam somente durante a noite e de terça-feira a domingo. O Beco dos Artistas, atualmente, possui o aspecto de um lugar bem deteriorado; o calçamento é esburacado, a rua é mal iluminada, possui contêineres de lixo nas extremidades e as paredes são sujas. Nos últimos anos, o lugar vem ganhando feições claras de um gueto ${ }^{1}$ e se encontra social e espacialmente separado do tecido social mais amplo da cidade. Talvez, por isso, o Beco permita em seu interior práticas e comportamentos que não são bem vistos fora do Beco.

O Beco concentra em seu interior uma imensa diversidade de comportamentos em termos de gênero e sexualidade; o lugar é frequentado por gays jovens ${ }^{2}$, gays velhos, lésbicas femininas, lésbicas masculinas, transformistas, travestis, bissexuais e michês. O intuito deste artigo, portanto, é pensar, à luz da teoria, como esses sujeitos, por meio das suas experiências vividas no lugar, questionam as normas hegemônicas no que se refere ao gênero, ao corpo e ao comportamento. 
Para tanto, este artigo se divide em duas partes: na primeira apresenta-se os pressupostos teóricos necessários para a análise dos dados coletados em campo. Esses pressupostos se sustentam em três teorias principais: a teoria da performatividade de Judith Butler (2008; 2002; 1999); a teoria do uso do corpo como princípio de transformação política advogada por Beatriz Preciado (2008); e a teoria da corporeidade e dos modos somáticos de atenção defendida por Csordas (2008). Depois de apresentada a teoria, são expostos os dados de campo e reflete-se sobre o potencial subversivo das práticas e dos comportamentos desses sujeitos dentro do Beco.

\section{A Performatividade, o Gênero e o Corpo}

Continuei observando e vi um rapaz que também chamou minha atenção. Ele estava vestido com uma calça xadrez, cinza e preta, uma blusa regata. Tinha o corpo bem definido, com os músculos aparecendo, mas, ao mesmo tempo, tinha algo de feminino naquele corpo, talvez a postura esguia, a bunda empinada e as pernas coladas. Isso gerava uma aparente contradição corporal, uma espécie de androgenia. Ao mesmo tempo em que os músculos definidos e à mostra expressavam uma masculinidade, esses mesmos músculos, dentro do conjunto corporal, levando em conta a postura esguia, a pequena abertura das pernas e a bunda empinada, pareciam conformar muito mais um arquétipo feminino, uma masculinidade dentro de uma totalidade feminina. Além disso, também, seu rosto parecia ser feminino e masculino ao mesmo tempo. O cabelo grande e cheio descia abaixo dos ombros, ele usava uma passadeira que fazia a parte de frente do cabelo ficar mais baixa, o que dava um contraste com a parte do fundo que sobressaia volumosamente. $O$ fato de ele estar usando uma passadeira deixava seu rosto mais exposto, um rosto também andrógino, o queixo quadrado dava um quê de masculinidade, enquanto o nariz fino e pontiagudo, junto com os olhos puxados e esverdeados the dotavam de um ar feminino. Fiquei observando aquele rapaz ali e achei bem interessante a ambiguidade expressada pelo seu corpo, uma ambiguidade corporal, que poderia, por vez, ser a expressão de uma ambiguidade ${ }^{3}$ subjetiva. (Diário de Campo, 4/6/2010) 
O período de campo no Beco, principalmente, o vivido no espaço da rua, por meio da observação participante, o que permitiu perceber o comportamento das pessoas, foi bem instigante para pensar a relação entre corpo, gênero e sexualidade. Butler $(2008 ; 2002 ; 1999)$ é uma das autoras que, por meio da sua teoria, nos permite analisar, de forma crítica e minuciosa, a relação que a estilização do corpo, através dos atos performativos, mantém com as identidades de gênero.

Butler $(2008 ; 2002 ; 1999)$ traz o corpo para sua teoria por meio da ideia de atos performativos. O gênero, ao invés de ser a continuidade de uma verdade fundamental ancorada no sexo, é a consequência de uma produção discursiva que se materializa e produz efeitos de realidade através do que ela chama de estilização do corpo ou estilização da carne. O corpo, para Butler, não tem um status ontológico separado de seus atos performativos. Se o gênero é performativo, o corpo também o é. É através dos atos performativos que o gênero se legitima como representante de uma essência corpórea e interior. O corpo, o uso do corpo - os gestos, a fala, o caminhar - é o que cria um efeito de realidade e dota o gênero de uma aparente materialidade. A materialidade é, para Butler, nesse sentido, construída por meio da atuação de atos performativos, ou por meio de uma "repetição estilizada de atos" que cria a ilusão de substância. É o corpo que dá a impressão de materialidade, ou de existência natural, as posturas construídas pelo discurso.

Em outras palavras, atos, gestos e desejo produzem o efeito de um núcleo ou substância interna, mas o produzem na superfície do corpo, por meio do jogo de ausências significantes, que sugerem, mas nunca revelam, o princípio organizador da identidade como causa. Esses atos, gestos e atuações, entendidos em termos gerais, são performativos, no sentido de que a essência ou identidade que por outro lado pretendem expressar são fabricações manufaturadas e sustentadas por signos corpóreos e outros meios discursivos. O fato de o corpo gênero ser marcado pelo performativo sugere que ele não tem status ontológico separados dos vários atos que constituem sua realidade. (Butler, 2008, p. 194)

Assim, para Butler (2008), o gênero é uma performance estilizada dos atos. O gênero não é, nesse sentido, um ato fundante, mas, ao 
contrário, é uma injunção normativa que necessita ser reafirmada através do corpo, por atos repetitivos, ao longo da existência dos indivíduos. O corpo é o meio através do qual uma norma discursiva se materializa. Sob essa perspectiva, ser homem ou ser mulher sai do âmbito de uma verdade fundante atemporal para entrar no campo de uma temporalidade socialmente constituída. Ser homem ou ser mulher não é uma verdade metafísica que emana do sexo biológico, mas são atos performáticos que precisam ser repetidos ao longo do tempo. É essa repetição que se exerce por meio do manejamento do corpo que gera o efeito de materialidade.

Aqui, o pensamento de Butler (2008) vai ao encontro do de Foucault (2007) quando ele questiona a verdade do sexo, ou seja, a ideia de que o sexo é uma realidade dada e prévia ao discurso. Para Foucault (2007), a sexualidade é um dispositivo de poder e saber que age sobre os indivíduos, no sentido de não só reprimir, como, também, de produzir e incitar prazeres e sexualidades. O sexo, nesse sentido, não é algo que está além do discurso, não é uma realidade selvagem, esperando ser desvelada; o sexo é uma instância que é acionada através da própria rede de saber e poder mobilizada pelo discurso.

Além disso, para Butler (2008), a performance repetitiva ou a reencenação estilizada do corpo é aquilo mesmo que legitima a norma e que dota a norma de um sentido de naturalidade. Um tipo específico de comportamento de gênero é o tempo todo afirmado e reafirmado através dos atos performativos dos indivíduos. Essa reencenação e essa atitude corporal coletiva legitimam uma norma social que é, ao mesmo tempo, causa e consequência dessas perfomances coletivas. Eu vejo minhas posturas sendo reafirmadas nas posturas dos outros. Assim, essa ação é antes de tudo uma ação pública, informada por uma norma social e por uma atitude corporal coletiva. “Essa repetição é a um só tempo reencenação e novas experiências de um conjunto de significados já estabelecidos socialmente; e também é a forma mundana e ritualizada de sua legitimação" (Butler, 2008, p. 200).

Essas normas sociais são tão interiorizadas, incrustam-se nos corpos que nem mesmo os atores mundanos tomam consciência de seu caráter contingente. Para os atores, eles são aquilo mesmo que 
encenam; o efeito de materialidade que o discurso produz através do corpo, seu caráter contingente, é desconhecido até mesmo para os atores que mundanizam essas normas sociais. O pensamento de Butler me lembra aqui a ideia de Bourdieu (1997), do habitus como uma auto-orquestração inconsciente, em que os próprios atores creem naquilo mesmo que eles legitimam e constituem. Os atores habituamse a agir de uma determinada maneira, ao ponto de essa atitude habituada não passar mais pela reflexão ou pela consciência, pois está já incrustada no corpo; o ator vê-se enredado numa trama que ele próprio alimenta, mas, da qual ele mesmo não tem consciência. Além disso, como Bourdieu (1997), Butler acredita que a realidade social se constitui por um processo de retroalimentação, em que as normas sociais se perpetuam por meio das atitudes incorporadas dos atores, dependem da carne dos sujeitos, ao mesmo tempo em que os atores são constituídos pelas normas sociais. A estrutura binária de gênero é, nessa perspectiva, fundadora e consolidadora do sujeito, ao mesmo tempo em que é constituída pelo sujeito.

Para Butler (2008), a paródia dessas posições de gênero é uma das formas de transformação política. Essa transformação só se daria através do uso do corpo, nas ações performativas de sujeitos que não correspondem a essas normas de gênero. Tais performances provocariam o que Butler (2008) chama de deslocamentos. Um indivíduo que apresenta performances em termos de gênero "incoerentes" com seu sexo anatômico - um indivíduo do sexo masculino que tem uma performance feminina, ou o contrário - mostra não só a possibilidade de existência de arranjos entre sexo e gênero que não os pressupostos pela norma mas, também, que a própria ideia de origem, de uma identidade prévia fixada no sexo de onde o gênero emana e da qual é sua expressão natural, é uma ideia falaciosa.

Como a ficção de naturalidade do sexo/gênero é construída pela estilização do corpo por meio de atos repetitivos, então, essa repetição estará sempre sujeita a falhas na construção e afirmação do ideal normativo de gênero. Isso significa que os atos estilizados pelos sujeitos nem sempre alcançam o objetivo de confirmar a ficção de naturalidade criada entre sexo/gênero. É quando essa manobra falha que, por meio 
das performances corporais dos sujeitos, o dispositivo de controle dos corpos e da sexualidade se torna explícito e a ficção de coerência entre sexo e gênero é desvelada.

Além de Butler (2008), Preciado (2008) também fala da importância do corpo para o entendimento das performances de gênero. Em seu livro "Testo Younqui", Preciado (2008) narra uma experiência autobiográfica de ingestão de testosterona no corpo. Ela mostra como o uso da testosterona foi modificando seu corpo - o odor do seu suor e a quantidade de suor, a quantidade de pelos, o aumento da libido sexual, o aumento de energia, a sensação de força. E mostra, também, como a modificação do corpo teve um efeito sobre sua subjetividade, ou seja, como o uso e manejamento do corpo produzem uma subjetividade específica.

Nesse sentido, ela afirma que a transformação dos parâmetros de gênero não tem que vir do discurso, mas da transformação do próprio corpo. Ela faz do corpo um espaço político por excelência e advoga um princípio que ela denomina de princípio autocobaia. A melhor forma de transformação das normas sociais, nessa perspectiva, seria a atuação sobre o próprio corpo, por meio da autoexperimentação corporal. Modificar o corpo é, nesse sentido, modificar as normas sociais e de gênero, assim, mais importante do que agir sobre as representações e sobre os discursos é agir sobre o corpo. É agindo sobre o corpo que se formam novas subjetividades e, com isso, novas alternativas políticas. É interessante como Preciado (2008) mostra como o uso do corpo está ligado à subjetividade masculina e à subjetividade feminina, como o manejar do corpo gera um tipo de temperamento, gera um sentido associado ao que é ser mulher e ao que é ser homem.

Ser homem e ser mulher implica em um sentido de si que é construído e consolidado através do uso do corpo. Preciado (2008) fala de oficinas de Drag Kings, onde mulheres aprendem a se comportar como homens. Essas oficinas utilizam um método teatral que decompõe a ação aprendida, nas performances masculinas e femininas, em unidades básicas que são examinadas como signos culturais e de construção de gênero. Atenta para o andar, para o falar, para o sentar-se e o levantar-se, o olhar, o fumar, o comer , o sorrir, para a distância entre as pernas, a abertura dos joelhos, a velocidade dos braços, a amplitude 
do sorriso. Tudo isso são formas, através do corpo, de construir uma subjetividade especificamente masculina.

Uma das experiências mais intensas e transformadoras da oficina teve lugar durante a primeira exploração da cidade como drag king. Caminhar, tomar um café, pegar o metrô, parar um táxi, sentar-se em um banco, fumar um cigarro apoiado contra o muro de um colégio [...], desenha-se assim, uma nova cartografia da cidade, até agora inexistente para um corpo codificado como feminino (tradução nossa). (Preciado, 2008, p. 262)

Preciado (2008) mostra como o uso do corpo codificado como feminino tem outro olhar sobre o mundo. Como o corpo condiciona modos de ser que, por sua vez, gera um tipo específico de olhar sobre o mundo, um tipo específico de subjetividade. Será que essas atitudes que Beatriz Preciado se refere, esse olhar sobre o mundo, esse modo específico de atentar para o mundo com o corpo não poderia se encaixar no que Csordas (2008) chama de modos somáticos de atenção?

Csordas (2008) desenvolve o conceito de "modos somáticos de atenção". Os modos somáticos de atenção são modos de atenção ao corpo e com o corpo. Atentar para o corpo não é atentar para um objeto que se encerra em si; atentar para o corpo é atentar mesmo para o mundo, para a situação desse corpo no mundo. A atenção é um "voltar-se para" e esse "voltar-se para" já é condicionado pela cultura. Cada cultura engendra modos de atenção específicos.

O manejamento do corpo, a forma como o corpo se posiciona no mundo constitui e é constituído pela cultura. Csordas afirma: “As maneiras pelas quais damos atenção aos e com os nossos corpos e, mesmo a possibilidade de dar atenção, não são nem arbitrárias, nem biologicamente determinadas, mas são culturalmente constituídas" (Csordas, 2008, p. 374). Aquilo que parece ser natural ou uma mera consequência da nossa existência biológica - a forma de usar o corpo, o jeito de andar, a forma de sorrir, o gesticular das mãos, a forma de falar - é, antes, o resultado de um ethos cultural específico e, ao mesmo tempo, a afirmação desse ethos.

O manejar do corpo acaba, nesse sentido, por constituir subjetividades. Um modo específico de atentar para o mundo com o 
corpo alimenta certo tipo de moral e condiciona um olhar específico sobre o mundo. O uso do corpo está ligado a "maneiras de ser" e "modos de fazer" específicos. O conceito de "modos somáticos de atenção" mostra que agir externamente, agir sobre o corpo é, também, produzir um tipo específico de interioridade. O engajamento sensorial é, também, uma forma de perceber o mundo, o que gera, por sua vez, um sentido específico de si. Assim, agir sobre o corpo é também agir sobre a subjetividade, sobre esse sentido de si.

Desse modo, quando Preciado (2008) afirma que um tipo de uso masculino do corpo "[...] desenha uma nova cartografia da cidade, ou do mundo, ou seja, desenha um novo olhar [...]" (Preciado, 2008), ela não estaria falando em modos somáticos de atenção? Em outras palavras, já que o uso do corpo gera um modo específico de atentar para o mundo, será que não podemos falar aqui em modos somáticos de atenção masculinos e femininos?

O que Beatriz Preciado (2008) mostra é que a masculinidade, a feminilidade, o gênero e o sexo, não podem ser compreendidos sem atentar para o corpo. Sem atentar para como esses ideais normativos conformam modos corporais e maneiras de ser e, ao mesmo tempo, como esses modos corporais permitem a internalização, a incorporação de normas sociais que, aparentemente, se expressam apenas na linguagem e no discurso. Ser homem e ser mulher é, antes de tudo, um modo de ser corporal.

\section{Os Frequentadores do Beco, o Corpo e o Comportamento}

O Beco dos Artistas se mostrou, no decorrer do trabalho de campo, um espaço muito rico para pensar a relação entre corpo, gênero e sexualidade. Em campo, percebi que algumas mulheres quando se comunicavam com outras de forma descontraída, muitas vezes, pegavam no meio das pernas, na região da vagina, apertavam o pano da calça como se estivessem pegando em um pênis e diziam: minha pica! Essa cena se repetiu diversas vezes em campo. Era comum, também, garotos se referirem ao seu órgão sexual como "buceta". Um entrevistado comenta sobre esse ato performativo realizado por algumas mulheres: 
$Y$ - Elas querem ser homem e não é homem. Qualquer motivo quer brigar, aí coça o negócio e não tem negócio para coçar e coça, quer tirar onda de homem, entendeu? E não é homem, é mulher, como a gente não é mulher, a gente é homem (grifo nosso). Qualquer coisinha quer encrencar, quer brigar, e brigam muito entre elas. Gay não, mas, elas brigam muito entre si.

I- Qualquer coisinha, se a namorada delas olhar para outra, elas ficam brigando, discutindo, não é igual aos gays.

Percebe-se que, para o entrevistado, o sexo biológico é aquilo mesmo que define a identidade de gênero de um indivíduo. O seu incômodo é notar que a performance de gênero dessas mulheres não é compatível com seu sexo biológico. É o contraste entre o corpo feminino e a masculinidade - que gera uma justaposição dissonante e tenciona a matriz de sexo e gênero pressuposta pelos sujeitos - o motivo do seu incômodo. O que ele é, assim como o que aquelas mulheres são, é, para ele, fruto do seu sexo biológico. O entrevistado presume a existência de um sexo original de onde emanaria a perfomance de gênero.

Para o entrevistado, o ato de "coçar o saco" é um ato masculino, que provém do fato dos homens possuírem pênis; é um ato que, supostamente, emanaria da anatomia dos corpos e que não poderia ser repetido por quem não tivesse um pênis para coçar. Ele diz: "não tem negócio para coçar e coça". Esse ato soa como falso, já que não existe ali o substrato biológico que autorize a sua realização. O que Butler (2008) nos mostra é que a paródia do gênero - o ato de uma mulher coçar o saco que ela não tem - não está na relação de uma cópia para um ato original, mas, de uma cópia para outra cópia. O fato de uma mulher poder coçar um pênis que ela não tem evidencia que esse ato no homem não emana necessariamente de sua anatomia, mas é tão performativo quanto o próprio gesto da mulher.

A fala do entrevistado também evidencia como muitas dessas mulheres que se utilizam mais dos atributos relacionados à masculinidade, ou que assumem uma performance mais masculina, são mal vistas pelos próprios frequentadores do Beco e por alguns donos de bares e são consideradas umas das responsáveis pelo estigma que recai sobre o Beco. São, muitas vezes, consideradas arruaceiras, sem 
educação e causadoras de problemas. A partir de entrevista feita com mulheres lésbicas, Facchini (2009) diz:

Entre a maior parte das entrevistadas, as masculinizadas são quase sempre citadas como 'outras' relativamente distantes, sendo criticadas por tornarem socialmente visíveis suas preferências eróticas, de um modo que poderia se tornar perigoso, e acusadas de procurar chocar ou agredir com sua aparência, o que poderia depor contra a imagem de todas as mulheres que gostam de mulheres. (Facchini, 2009, p. 322)

Quando Facchini (2009) diz que essas mulheres mais masculinizadas são acusadas de chocar ou agredir com sua aparência, é preciso pensar, também, por que tal aparência se apresenta como chocante ou agressiva e em quais contextos de significados elas os são. Assim, assumir que tais posturas são agressivas é também assumir que existe um contexto de significados, em termos de gênero e sexo, que as coloca nessa posição. "Um conjunto decididamente heterogêneo que engloba discursos, instituições, organizações arquitetônicas, decisões regulamentares, leis, medidas administrativas, enunciados científicos, proposições filosóficas, morais [...]" (Foucault, 1985, p. 244) que conformam o que Foucault (2007) chama de dispositivo da sexualidade. É esse dispositivo de controle e produção, a serviço sempre de um tipo de parentesco tido como heterossexual (Butler, 2003) que coloca tanto os homens como as mulheres, que não correspondem à coerência pressuposta e exigida entre sexo/gênero/desejo/prática sexual (Butler, 2008), em uma posição de marginalidade e, por conseguinte, capaz de chocar e agredir ${ }^{4}$.

Do mesmo modo, percebe-se na fala do entrevistado, quando ele diz que ele não é mulher que ele é homem, o que Peter Fry (1982) chama de sistema hierárquico de classificação da sexualidade que tem como parâmetro o gênero. Esse sistema divide os homens em machos e "bichas". Os homens machos são masculinos e ocupam o papel de ativos na relação sexual, já as "bichas" são homens efeminados e ocupam a posição de passividade na relação sexual. "Assim, o ato sexual entre pessoas do sexo masculino significa e é constitutivo da hierarquia que se estabelecem nas relações sociais [...]" (Fry, 1982, p. 92), as "bichas" são as que carregam o estigma por adotarem o gênero 
"incompatível" com seu sexo, enquanto os machos gozam da posição de homem por manter essa coerência entre sexo e gênero.

Assim, para o entrevistado, embora ele faça sexo com outros homens, isso não lhe retira o status de homem e, nesse caso especificamente, de macho, já que ele procura manter um comportamento de gênero adequado ao seu sexo. Para ele, então, o que se configura como problema não é a sexualidade de aquelas mulheres, ou a sua própria sexualidade, mas o fato de elas assumirem uma performance de gênero que não corresponde ao seu sexo biológico.

No decorrer do trabalho de campo, foi possível observar outros comportamentos que, também, são frutíferos para pensar as relações de gênero. As únicas brigas que presenciei, em campo, cujo fim foi agressão física, foram entre mulheres que possuíam traços mais masculinos. Descreve-se uma dessas brigas no relato de campo:

Nesse mesmo momento, começou uma confusão na frente do Green Bar. Um amontoado de pessoas, as pessoas caindo no chão e muito barulho. Era uma briga entre duas mulheres, mas em que as amigas acabaram se envolvendo. A confusão durou cerca de cinco minutos, depois saíram duas meninas sendo arrastadas e seguradas para que uma não avançasse sobre a outra. Despenteadas, rostos vermelhos, uma queria avançar sobre a outra, mas os amigos as seguravam, até que, depois de muita agitação, elas se acalmaram. Nesse momento, eu já tinha pedido licença às pessoas com quem eu estava conversando e tinha me aproximado para ver o que estava acontecendo. Uma das meninas que saiu arrastada, agora estava sentada mais calma e a outra menina parecia ser sua amiga, chegou perto dela, levantou o braço em direção ao seu rosto, apertou o seu punho e falou com raiva: "eu quebrei a cara dela, quebrei a cara dela". Depois disso, se levantou e foi até o local da briga, ficou procurando algo, até que se agachou e pegou uns óculos todo empenado, com a lente quebrada, por fim, voltou para junto da amiga. (Diário de campo, 16/10/2009)

E na entrevista com a garota que participou da briga:

E: Você já presenciou alguma briga aqui?

A.C: Várias, inclusive eu já fiz parte de uma. (risos) 


\section{E: Conta essa história.}

A.C: A menina estava de onda comigo, não comigo, com minha irmã aí ela foi brigar com minha irmã, a namorada dela se meteu e eu me meti também. O pau começou a comer, foi aquilo tudo, todo mundo batendo em todo mundo, sorte que eu não saí machucada, graças a Deus, eu não me machuquei. Teve outra briga, também, que o menino chegou aqui embriagado, encontrou a namorada aqui dando corno nele com outra mulher, chegou e deu uma garrafada na cara dela.

E: Na cara?

A.C: Na cara da mulher, exatamente. Aí foi a partir daí que o pessoal começou a botar segurança para poder evitar as brigas aqui.

E: E por que essa menina cismou com sua irmã?

A.C: Ela era ex-namorada da menina que eu estava ficando, que eu estava namorando. Aí ela procurou briga comigo, eu fui para cima dela, só que eu não estava muito bem, já estava grogue de cachaça, minha irmã tomou a frente, tomou a briga, ela disse que não ia ficar por isso. Aí, na sexta-feira seguinte, ela veio e procurou briga com minha irmã, eu estava devendo uma porrada a ela, voltei para a briga, entendeu?

E: Mas você bateu, apanhou?

A.C: Rapaz, ela tomou pau para porra, viu? Tanto ela quanto a namorada, tomou um pau lerdo, viu? Literalmente.

Algumas pessoas, quando se referem a esse comportamento mais agressivo de algumas mulheres no Beco, chegam a falar de uma inversão psicológica desses indivíduos. Estela, responsável pelo Green Bar, diz que as pessoas que frequentam seu bar são mais casais, principalmente, lésbicas. Diz que já viu várias cenas de ciúmes e que as mulheres são mais agressivas que os homens. "É como se os papéis tivessem invertido, enquanto os homens são mais delicados, as mulheres são mais agressivas", diz Estela. Conta já ter visto uma briga entre duas mulheres de tirar sangue e, dentro do seu próprio bar, duas mulheres grudadas uma no cabelo da outra. Contou que, outro dia, tinha um casal de lésbicas e um rapaz passou e olhou, uma das mulheres levantou e foi em direção ao rapaz, querendo bater no rapaz, só não o agrediu, porque o marido de Estela entrou na frente. Disse que, embora entre os homens exista muito ciúme, ela nunca presenciou uma briga que levasse a agressão física. Estela contou que, um dia, estava um casal na mesa e eles pediram um escondidinho. Ela caprichou no escondidinho e pediu para o garçom ir servir, o garçom foi e, depois de dez minutos, 
o garçom voltou com o escondidinho intacto. Ela, então, pergunta ao garçom: mas o que aconteceu, eles não gostaram do escondidinho? E o garçom respondeu: não, é que eles brigaram. Por ciúmes um levantou e o outro foi atrás.

Marcelo, responsável pelo Bar Cultural, também fala do comportamento dos homens e mulheres ali, como se existisse uma inversão de papéis.

E: Você acha que ocorrem mais brigas entre homens ou entre mulheres? M: Mulheres. Raramente gays brigam, gays batem boca e discutem. Um quer ser melhor do que o outro na cultura. Quer botar o outro no chão com palavras. Mulher não; mulher joga a garrafa, querem quebrar garrafa, algumas delas, outras não. Isso mais as machudas. E as bichas mais femininas querem bater boca, e ai vai. Querem esculhambar, uma diz que o cabelo da outra está feio, a outra diz que não sei o quê. Porque, da mesma forma que há uma troca no sexo em relação a isso, ao prazer, eu não sei se psicologicamente eles acabam trocando o papel (grifo nosso). Porque, quem bate muita boca e quem discute muito é a mulher. A heterossexual discute muito. O heterossexual é logo na porrada. Homem que é homem vai logo para porrada. Então há uma troca. Pelo que eu vi de uma mulher muito machuda, ela não sai batendo boca, ela não vai se esquentar à toa. E a bichinha feminina, ele não é de brigar, é de ficar discutindo, esculhambando o outro, dizendo que o outro é isso e aquilo. Então, as briga que eu já vi aqui são mais de mulheres. Já teve briga entre homens, mas, é como eu disse para você, teve uma briga semana passada, mas não eram gays. Então de gays mesmo, é mais briga com mulher.

Em todos esses comportamentos está presente uma performance de gênero, uma estilização do corpo, ou o que Csordas (2008) chama de modos somáticos de atenção, um modo específico de atentar com o corpo para o mundo e, ao mesmo tempo, um modo específico de atentar para o corpo. Esse uso do corpo presente no comportamento dessas mulheres mais masculinas e dos homens afeminados, também conforma subjetividades, ao ponto desses garotos e dessas garotas não se sentirem representados(as) pelos ideais do que é ser homem ou do que é ser mulher. Essa subjetividade deslocada permite a esses garotos e garotas um novo olhar sobre o mundo, e a estilização dos seus corpos - atos performativos repetidos e retificados - na medida em que tencionam a matriz normativa do gênero, carregam o que Butler 
(2008) chama de um potencial subversivo. Beatriz Preciado (2008), também, coloca como uma performance masculina, aprendida nas oficinas de Drag Kings, por meio do uso do corpo, é capaz de gerar um tipo de temperamento, um sentido de si associado à ideia do que é ser homem ou do que é ser mulher. Um trecho do diário de campo toca nessa questão da subjetividade e da performance corporal.

Fiquei observando aquelas meninas de 15, 16 e 17 anos que estavam dançando na pista de dança. Havia algumas meninas com posturas bem masculinas, boné para traz, calça jeans ou bermuda e blusa folgada, e outras meninas com atributos mais femininos, uma de vestido azul e curto, cabelo liso e preto nos ombros, outra com uma blusa decotada, uma calça colada, cabelo longo, liso e preto, e outras mais despojadas, nem tão masculinas nem tão femininas. As duas garotas, com performances mais masculinas, pareciam ser os machos alfas da pista de dança. Elas tinham todo um gestual de homem cafajeste, passavam a língua por entre os lábios, peito estufado, cabeça erguida, boné para trás, tiravam e colocavam o boné, e parecia que todas as outras meninas, que manejavam os atributos mais femininos, os(as) disputavam. Elas vinham e pegavam, uma pela cintura, depois pegava outra, dançavam com a mão na bunda das garotas. Naquele momento, uma delas parecia dançar mais consigo mesma do que com as garotas com quem ela interagia, numa atitude narcísica de afirmação da sua masculinidade. Quando ela beijava uma garota era como se ela estivesse beijando a si mesma; seu gozo, prazer, e sua satisfação, naquele momento, estavam mais na afirmação de sua masculinidade e aquelas garotas em volta serviam mais como suporte para essa afirmação do que como real objeto de desejo. A cena me remeteu muito mais a um gozo em termos de performance de gênero do que, propriamente, sexual, se é que essas coisas podem ser separadas. A sua atenção estava voltada para o seu "modo de ser" corporal. (Diário de campo, 2/10/2009)

Os atos corporais dessa garota, assim como de outras garotas que manejam corporalmente os atributos da masculinidade, atuam na formação de uma masculinidade performativa e de uma subjetividade que, ao mesmo tempo em que se manifesta pelos atos corporais, também 
é reafirmada por meio destes. Esses atos performativos de garotos e garotas que frequentam o Beco são muito menos consequência da inversão de uma atitude original e referenciada no sexo do que consequência da multiplicidade de formas e arranjos entre gênero e sexo que podem existir na vida cotidiana. Esses indivíduos, frequentadores do Beco, de algum modo, frustram a perspectiva de infalibilidade das normas de gênero e sexo. Eles trazem em seus corpos e em suas performances um imenso potencial subversivo, capaz de desvelar o caráter de controle do dispositivo da sexualidade, já que elucidam que o comportamento dos indivíduos não é a expressão direta de uma natureza biológica, mas, são performances condicionadas e controladas pela matriz normativa do sexo/gênero/desejo/prática sexual que sustenta a heterossexualidade compulsória.

\section{Considerações Finais}

Os frequentadores do Beco estão, a todo momento, questionando as normas de gênero vigentes. O ato de "coçar o saco" praticado por algumas mulheres, o comportamento agressivo de outras, o manejo de atributos femininos por corpos masculinos, o uso de adereços como brincos, batons, bolsa, a mistura desses signos em distintos corpos desestabilizam a ideia de um gênero fundamentado no sexo biológico e de uma coerência necessária entre sexo/gênero/desejo e prática sexual. Evidencia-se por meio da experiência desses sujeitos que o gênero, como afirma Butler (2008), não é uma substância, não é uma natureza revelada pela verdade do sexo, mas é, antes de tudo, um ato performativo, cuja materialidade é constituída através da repetição estilizada dos atos.

O comportamento daqueles sujeitos no interior do Beco dos Artistas, o rebolado do caminhar de alguns garotos, a sinuosidade do corpo, o modo de posicionar as pernas e o glúteo mostram que o gênero consiste em uma estilização do corpo, em um modo de atentar para o mundo com o corpo. Esse modo de atentar para o mundo, como afirma Csordas (2008) constitui subjetividades. Esse temperamento estimulado pela estilização do corpo pode ser considerado o fundamento daquilo que denominamos como masculinidade e feminilidade. Preciado (2008) 
já chamava a atenção para o fato de que ser homem ou ser mulher implica em um sentido de si que é consolidado pelo uso do corpo.

Para Butler (2008), as normas hegemônicas de gênero só se sustentam por via de uma repetição de atos performativos que supõe dizer uma verdade inexorável sobre o que é ser homem e o que é ser mulher. Essa repetição dos atos performativos, que definem tanto o que é ser homem quanto o que é ser mulher, não só diz respeito a subjetividades privadas, mas possuem, acima de tudo, um caráter público marcado por uma repetição coletiva desses atos. É essa repetição coletiva de atos performativos que fornece consistência as normas hegemônicas de gênero. No entanto, por seu caráter mesmo repetitivo, essas normas estão sujeitas a falhas ou recriações.

Quando uma garota no Beco usa uma cueca e deixa a borda dessa cueca aparecer por entre sua calça folgada, usa um boné para trás e uma blusa larga que impede a percepção dos seus seios, essa garota está provocando o que Butler (2008) chama de um deslocamento das normas de gênero. Esse deslocamento possui um imenso poder subversivo, pois além de elucidar a possibilidade de configurações outras entre o corpo e o gênero, elucida também o caráter opressor dessa norma hegemônica quando ela pressupõe uma continuidade direta entre sexo biológico e performance de gênero.

Por fim, o que o comportamento dos frequentadores do Beco dos Artistas elucida não é uma inversão de papéis entre homens e mulheres - pois para falar em inversão é preciso que se suponha um substrato anterior a estilização do corpo e a performance de gênero que fundamente tal inversão - mas sim a enorme variedade de arranjos em termos de corpo e gênero que pode existir nos interstícios mesmo da vida cotidiana. Esses sujeitos que brincam com os signos do gênero tornam explícito a fragilidade desse dispositivo de poder e de controle que se transfiguram em normas sociais e que, ao mesmo tempo, perscrutam as subjetividades desses sujeitos. 


\section{Notas}

1 Muitos autores recorrem ao conceito de "gueto gay". Simões e França (2005) definem o "'gueto homossexual' como espaços urbanos públicos ou comerciais parques, praças, calçadas, quarteirões, estacionamentos, bares, restaurantes, casas noturnas, saunas - onde as pessoas que compartilham uma vivência sexual possam se encontrar". Perlongher (1987) utiliza a categoria "gueto gay" para descrever as zonas de sociabilidade homossexual em São Paulo e afirma a validade da noção de "gueto gay" como uma construção sociológica.

2 A grande maioria dos jovens, gays e lésbicas, que frequentam o Beco dos Artistas é de cor de pele negra e de baixo poder aquisitivo. A intersecção entre essas categorias - a sexualidade, o gênero, o fenótipo e a classe - conflui para uma forte estigmatização do lugar. Essa estigmatização é resultado da articulação, no espaço, desses fatores. Cabe lembrar aqui Piscitelli (2008) que, ao discutir o conceito de interseccionalidade, ressalva a importância de capturar as consequências da interação entre dois ou mais eixos de subordinação. Sem dúvida alguma, a confluência desses eixos de subordinação contribuiu para a relação de estigmatização que o tecido socioespacial mais amplo estabelece com o lugar - Beco.

3 Ambiguidade aqui quer dizer não insegurança, ou, algo de caráter duvidoso, mas, aquilo que pode tomar e ter mais de um sentido. Os sentidos de masculinidade e feminilidade se misturam nesse corpo e nessa subjetividade.

4 É fato que, dentro do Beco, o incômodo que existe em relação às mulheres mais masculinizadas tem relação com um tipo de comportamento dessas mulheres que está para além da performance de gênero. Isso, no entanto, não faz com que essa "incoerência" entre sexo e gênero não seja um dos fatores relevantes para essa opinião negativa em relação a tais mulheres.

\section{Referências}

BOURDIEU, Pierre. O conhecimento pelo corpo: Meditações

Pascalianas, Rio de Janeiro: Bertrand Brasil, 1997. p. 157-198.

BUTLER, Judith. Corpos que pesam: sobre os limites discursivos do "sexo". In: LOURO, G. L. O corpo educado: pedagogias da sexualidade. Belo Horizonte: a Autêntica, 1999. p. 151-172.

BUTLER, Judith. Criticamente Subversiva. In: JIMÉNEZ, Rafael M. Mérida. Sexualidades transgresoras: una antología de estudios queer. Barcelona: Icária editorial, 2002. p. 55-81.

BUTLER, Judith. Problemas de Gênero. Rio de Janeiro: Civilização Brasileira, 2008.

CSORDAS, Thomas. Modos somáticos de Atenção: corpo, significado e cura. Porto Alegre, RS: UFRGS Editora, 2008. p. 367-392. 
FACCHINI, Regina. Entrecruzando diferenças: mulheres e (homo) sexualidades na cidade de São Paulo. In: DÍAZ-BENÍTEZ, Maria Elvira; FÍGARI, Carlos Ciro (Org.). Prazeres Dissidentes. Rio de Janeiro: Garamond, 2009. p. 309-342.

FOUCAULT, Michel. História da sexualidade 1: a vontade de saber. Rio de janeiro: Graal, 2007.

FOUCAULT, Michel. Sobre a história da sexualidade. In: FOUCAULT, Michel. Microfísica do poder. Rio de Janeiro: Graal, 1985. p. 243-276.

FRY, Peter. Para Inglês ver: identidade e política na cultura brasileira. Rio de Janeiro: Zahar, 1982.

PRECIADO, Beatriz. Texto Younqui. Madrid: Editora Espasa Calpe, S.A., 2008.

PERLONGHER, Nestor. O negócio do michê: prostituição viril em São Paulo. São Paulo: Editora Brasiliense, 1987.

PISCITELLI, Adriana. Interseccionalidade, categorias de articulação e experiências de migrantes brasileiras. Sociedade e Cultura, [S.l.], v. 11 , n. 2, p. 263-274, jul./dez. 2008.

SIMÕES, Júlio Assis; FRANÇA, Isadora Lins. Do Gueto ao mercado. In: GREEN, James Naylor; TRINDADE, Ronaldo; SILVA, José F. B. da (Org.). Homossexualismo em São Paulo: e outros escritos. São Paulo: Editora UNESP, 2005. p. 309-336.

Recebido em 02/11/2015

Aceito em 24/06/2017 